\begin{tabular}{|c|c|c|c|c|c|}
\hline JRL & Vol. 12 & No. 2 & Hal : 118 - 135 & $\begin{array}{c}\text { Jakarta, } \\
\text { Desember 2019 }\end{array}$ & $\begin{array}{c}\text { p-ISSN : 2085.38616 } \\
\text { e-ISSN : 2580-0442 }\end{array}$ \\
\hline
\end{tabular}

\title{
KONDISI SOSIAL-EKONOMI DAN PERSEPSI MASYARAKAT DI SEKITAR LUBANG BEKAS TAMBANG BATUBARA
}

\author{
Satmoko Yudo dan Taty Hernaningsih \\ Pusat Teknologi Lingkungan, BPPT
}

Gedung Geostech 820 Lt.2, Kawasan Puspiptek, Tangerang Selatan, Banten Email : satmoko.yudo@bppt.go.id dan tatyhernaingsih@gmail.com

\begin{abstract}
Abstrak
Sejak tahun 2000 an industri pertambangan batubara khususnya di Kalimantan semakin marak, hal ini membawa dampak yang sangat merugikan bagi lingkungan. Kini ribuan lubang bekas tambang dibiarkan tanpa pengelolaan dan tidak dimanfaatkan oleh penduduk sekitarnya. Lubang bekas penambangan yang ditinggalkan pada akhir kegiatan tambang tanpa adanya perencanaan pemanfaatan berpotensi menimbulkan dampak yang tidak diinginkan bagi lingkungan dan masyarakat sekitarnya. Dua lubang tambang bekas tambang sejak tahun 2010 sampai saat ini belum dimanfaatkan baik oleh perusahaan maupun masyarakat di sekitarnya. Untuk mengetahui persepsi masyarakat tentang keberadaan lubang bekas tambang maka telah dilakukan survei ke beberapa penduduk di sekitar lubang bekas tambang tersebut. Hasil survey menunjukkan bahwa masyarakat sebagian besar setuju dengan rencana pemanfaatan lubang bekas tambang sebagai reservoir sumber air khususnya sebagai air bersih. Sebagian kecil masyarakat mempunyai pemikiran selain sebagai sumber air yaitu sebagai obyek wisata, tambak ikan nila, tempat pemancingan ikan dan untuk pengairan sawah dan ladang. Hasil survey ini akan menjadi dasar pertimbangan dalam merencanakan bentuk pemanfaatan dari void tersebut.
\end{abstract}

Kata kunci :lubang bekas tambang, persepsi masyarakat, reservoir sumber air. 


\title{
SOCIAL ECONOMIC CONDITION AND PUBLIC PERCEPTION IN AROUND OF COAL MINING VOIDS
}

\begin{abstract}
Since the 2000s, the coal mining industry, especially in Kalimantan, has become more widespread, this has a very detrimental impact on the environment. Now thousands of ex-mining void are left without management and not utilized by surrounding residents. Ex-mining voids left at the end of mining activities without any utilization planning have the potential to cause undesirable impacts on the environment and surrounding community. Two ex-mining voids since 2010 have not been utilized by companies or the surrounding communities. To find out public perceptions about the existence of ex-mine holes and utilization plans that will be carried out by the company, a survey has been carried out on several residents around the ex-mine pit. The survey results showed that the majority of the community agreed with the plan to use ex-mining void as a reservoir of water resources especially as clean water. A small part of the community has thought other than as a source of water, namely as a tourist attraction, tilapia fishponds, fishing grounds and for irrigating rice fields and field. The result of this survey will be the basis for consideration in planning the form of utilization of the voids.
\end{abstract}

Keywords : ex-mine hole, public perception, reservoir of water resources 


\section{PENDAHULUAN}

\subsection{Latar Belakang}

Di Indonesia, batubara saat ini menjadi komoditi idola dari dunia pertambangan. Walaupun jumlah cadangan batubara di Indonesia hanya sekitar $3 \%$ dari jumlah batubara di dunia, namun saat ini Indonesia adalah pengekspor batubara terbesar di dunia (Bappenas, 2016).Di dalam negeri, batubara telah memainkan peran yang cukup penting bagi perekonomian Indonesia. Peran batubara sebagai sumber energi pembangkit juga semakin besar, mengingat sekitar $71,19 \%$ dari konsumsi batu bara domestik diserap oleh pembangkit listrik, $17 \%$ untuk industri semen dan $10 \%$ untuk industri tekstil dan kertas (Josua, M. 2012).

\section{Permasalahan}

pada

penambangan batubara secara tambang terbuka dengan metode backfill dapat meninggalkan lahan bekas penambangan berupa lubang bekas tambang (void). Lubang bekas tambang yang ditinggalkan pada akhir kegiatan tambang tanpa adanya perencanaan pemanfaatan berpotensi menimbulkan dampak yang tidak diinginkan bagi lingkungan.

Adanya lubang bekas penambangan yang terisi air (void) pada akhir kegiatan penambangan ini tentu memerlukan pengelolaan agar dalam perjalanan waktu tidak membahayakan masyarakat dan dapat dimanfaatkan untuk kepentingan masyarakat.

Pengelola pertambangan wajib membuat rencana pemanfaatan void yang meliputi stabilisasi lereng, pengamanan void, pemulihan kualitas air dan pengelolaan air dalam void sesuai peruntukkannya dan pemeliharaan void. Penjaminan terhadap pengelolaan void menjadi bagian penting seperti tercantum dalam Peraturan Pemerintah Nomor 78 Tahun 2010 tentang Reklamasi dan Pasca tambang (Anonimous, 2010) dan Peraturan Menteri Energi dan Sumber Daya Mineral Republik Indonesia Nomor 7 Tahun 2014 tentang Pelaksanaan Reklamasi Pasca tambang pada Kegiatan Usaha Pertambangan Mineral dan Batubara (Anonimous, 2014).

Sebagai dasar pertimbangan dalam melakukan upaya pemanfaatan void perlu dilakukan kajian tentang keragaan/karakteristik setiap void baik secara fisika, kimia, biologi maupun ditinjau aspek sosial ekonomi.

Salah satu dasar pertimbangan pemanfaatan void adalah mengetahui kondisi sosial ekonomi dan persepsi masyarakat yang berada disekitar void.

\subsection{Tujuan}

Tujuan yang ingin dicapai dalam kegiatan ini adalah untuk mengetahui kondisi sosial ekonomi dan presepsi masyarakat yang berada di sekitar void dalam mencari bentuk pemanfaatan darivoid tersebut.

\section{BAHAN DAN METODOLOGI}

Lokasi survei ditentukan berdasarkan kepada lokasi desa yang terdekat dan di sekitar lokasi void yaitu Antasena barat dan Antasena timur. Lokasi desa-desa ini berada di Kecamatan Kintap, Kabupaten Tanah Laut, Provinsi Kalimantan Selatan. Adapun desa-desa tersebut adalah sebagai berikut:

1. Desa Riam Adungan,

2. Desa Salaman,

3. Desa Kintapura,

4. Desa Pasir Putih. 


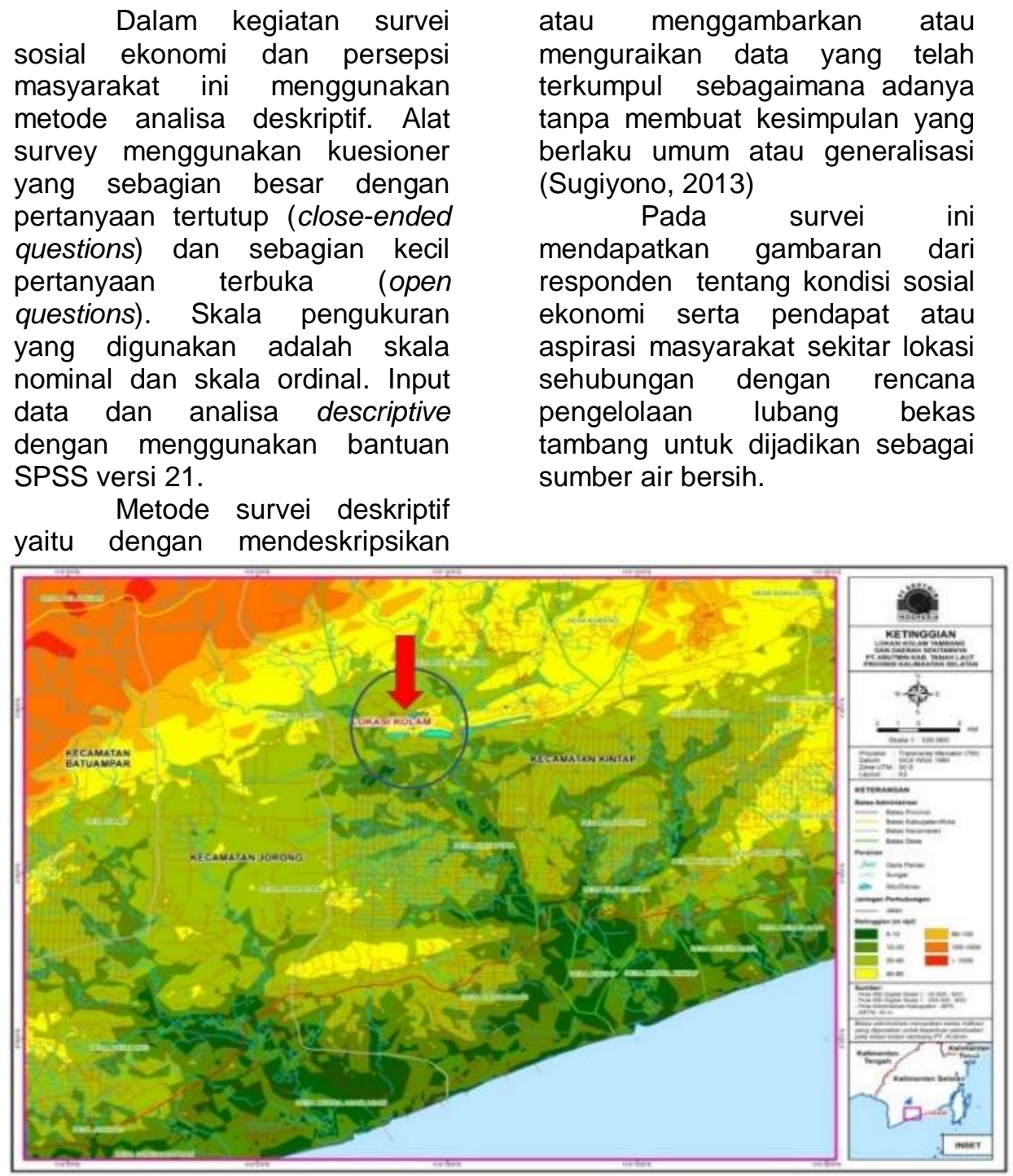

Gambar 1. Peta void di Kabupaten Tanah Laut, Propinsi Kalimantan Selatan (Sumber: PT. Arutmin Indonesia) 


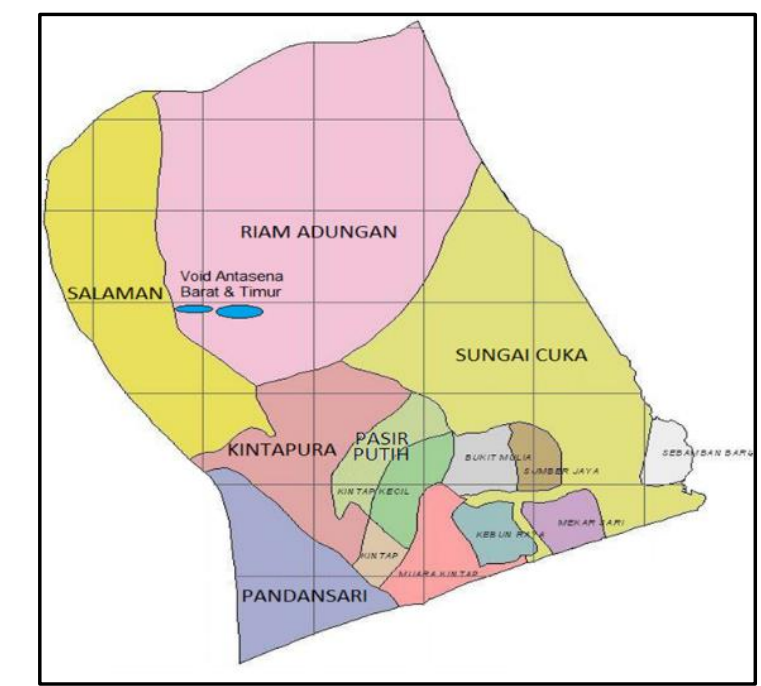

Gambar 2. Peta lokasi survey di Kecamatan Kintap

(Sumber : Kecamatan Kintap Dalam Angka 2017)

\section{HASIL DAN PEMBAHASAN}

Untuk mendapatkan kondisi sosial-ekonomi dan presepsi masyarakat terhadap pemanfaatan lubang bekas tambang (void) yang sudah terisi air, maka hasil analisa kuesioner terhadap masyarakat di sekitar void akan diuraikan seperti dibawah ini.

Berdasarkan hasil kuesioner diperoleh sebaran umur responden yang paling banyak adalah antara 35 44 tahun (30\%), diikuti responden yang berumur 45 - 54 tahun (23,3\%), kemudian 25 - 34 tahun (20\%) dan termuda dibawah 15 tahun. Terlihat sebagian besar masyarakat desa termasuk dalam usia produktif (15-64 tahun), Di masa produktif, secara umum semakin bertambahnya umur maka pendapatan akan semakin meningkat, yang tergantung juga pada jenis pekerjaan yang dilakukan (Putri, A.D.\& Setiawina, N.D. 2013) serta diharapkan pertumbuhan ekonomi desa tersebut. Kelompok ini juga dapat mewakili sebagian masyarakat di sekitar void.

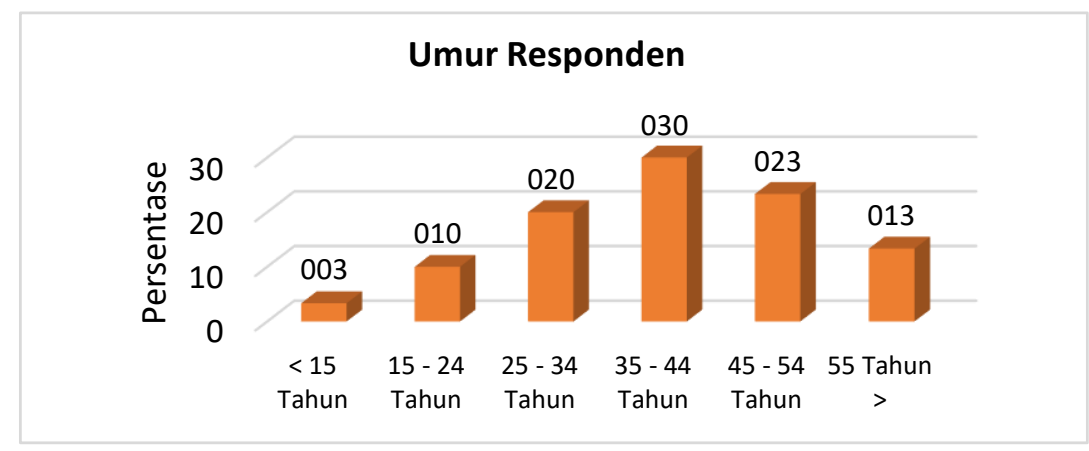

Gambar 1. Umur Responden di 4 (empat) Desa 
Sebagian besar responden mempunyai tingkat pendidikan tamatan Sekolah Dasar (30\%), kemudian diikuti SLTA (26\%) sebagai tingkat pendidikan terbanyak kedua. Pendidikan tertinggi adalah Sarjana (S1) sebesar $6,7 \%$ dan yang tidak mencapai tingkat SD hanya $13,3 \%$. Rendahnya tingkat pendidikan di daerah ini disebabkan karena fasilitas pendidikan formal di 4 (empat) desa hanya ada sekolah dasar. Fasilitas pendidikan yang lebih tinggi seperti SLTP, SLTA atau SMK belum tersedia. Dalam meningkatkan pembangunan manusia salah satunya adalah terjangkaunya fasilitas pendidikan, hal ini merupakan kunci dalam mengoptimalkan potensi penduduk menjadi potensi ekonomi (Jati, W. R., 2015). Penduduk usia sekolah harus ke ibukota kecamatan terdekat untuk melanjutkan pendidikan yang lebih tinggi dari SD. Hanya sebagian kecil saja warga yang berpendidikan setingkat perguruan tinggi/akademi $(6,7 \%)$.

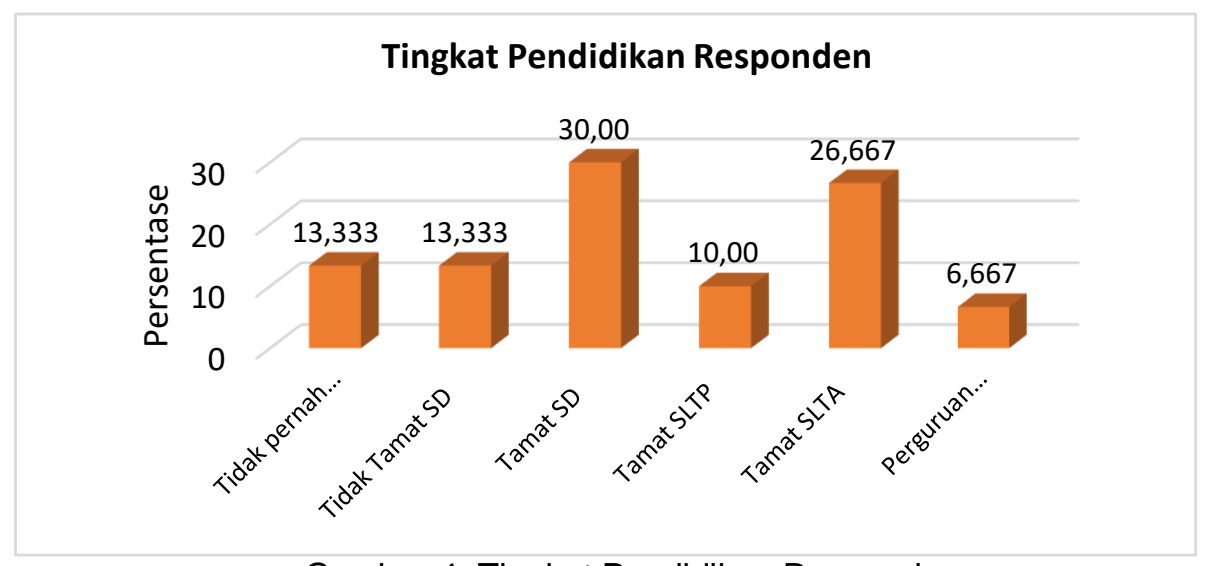

Gambar 4. Tingkat Pendidikan Responden

Mata pencaharian penduduk desa di sekitar reservoir bekas tambang bervariasi mulai dari buruh, petani sampai pegawai negeri atau swasta. Sebagian besar responden mempunyai pekerjaan sebagai pegawai swasta $(20,0 \%)$ umumnya mereka bekerja di perusahaanperusahaan kelapa sawit dan tambang batubara. Kemudian diikuti oleh pegawai negeri $(16,7 \%)$ dan pedagang (16,7\%). Pegawai negeri bekerja sebagai kepala desa dan aparat kelurahan serta pegawai Puskesmas, sedangkan pedagang mulai dari pedagang kain keliling sampai pedagang kayu. Mata pencaharian lainnya yang tidak begitu banyak adalah sebagai buruh dan petani $(13,3 \%)$, umumnya mereka bekerja di bidang kelapa sawit. 


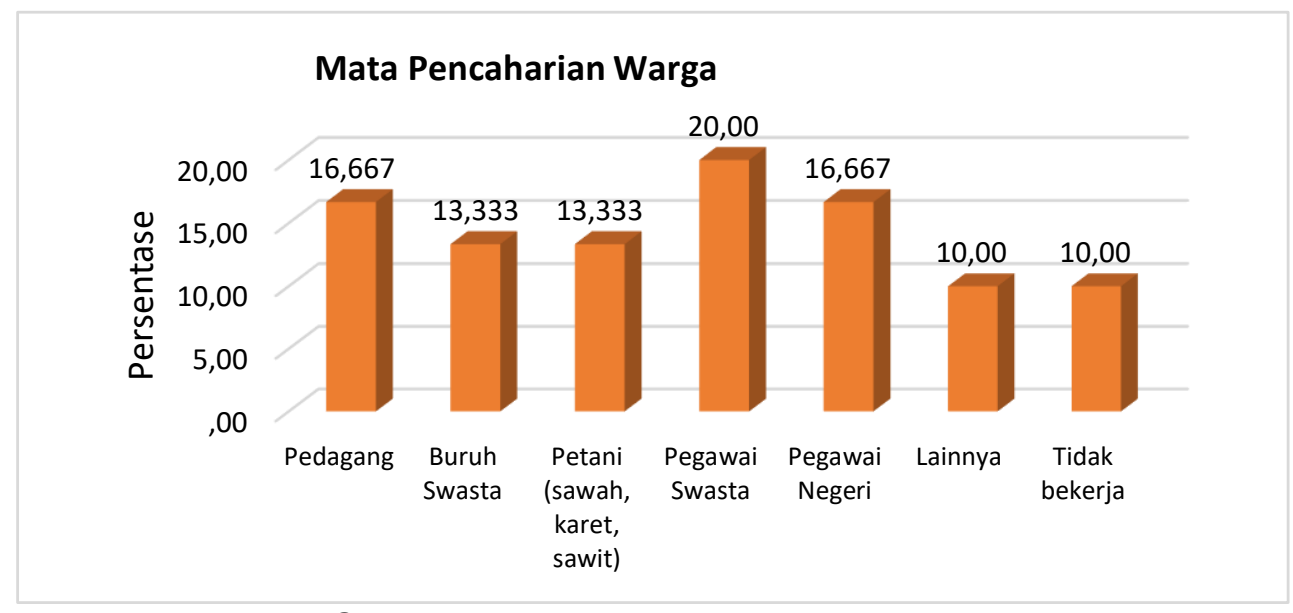

Gambar 5. Mata Pencaharian Warga

Sebagian besar (40\%) 500.000,-. Secara umum penduduk di penghasilan responden di atas Rp. 4 desa ini di atas batas garis 2.000.000,-, diikuti yang kemiskinan (Menurut Menteri berpenghasilan Rp. 1.500.000,- Perencanaan Pembangunan sampai Rp. 2.000.000,-. Hanya Nasional/PPN tahun 2016, batas garis sebagian kecil saja yang kemiskinan yakni sebesar Rp. berpenghasilan dibawah Rp. 362.990 per kapita per bulan).

\section{Penghasilan Responden per Bulan}

(Rupiah)

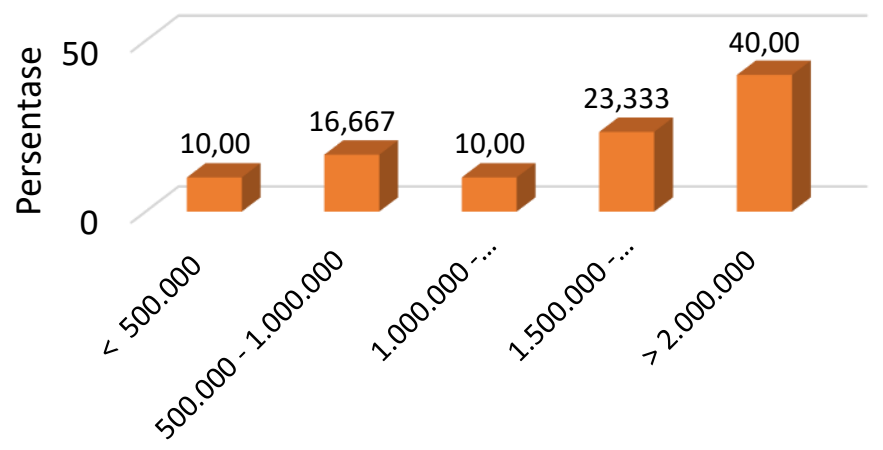

Gambar 6. Penghasilan Warga per Bulan 
Sumber air untuk digunakan sebagai air minum sebagian besar $(36,7 \%)$ warga berasal dari air sumur gali, sebagian lagi (30\%) berasal dari air sungai. Selain itu warga (20\%) juga ada yang membeli air untuk kebutuhan air minumnya. Hanya sebagian kecil warga $(6,7 \%)$ yang mengambil sumber air dari danau untuk digunakan sebagai air minum.

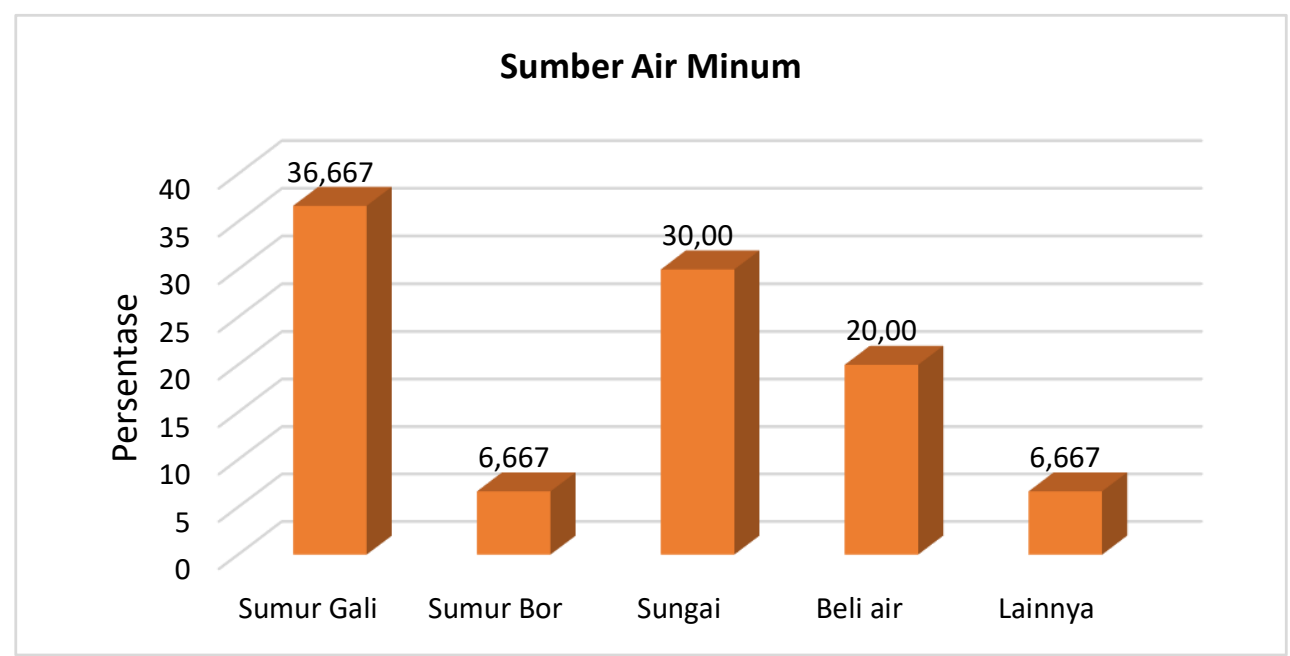

Gambar Error! No text of specified style in document.. Sumber Air untuk Minum

Hasil analisa (Tabel 1) kualitas air di salah satu sumur penduduk menunjukkan bahwa seluruh parameter memenuhi baku mutu untuk penggunaan air bersih sesuai dengan Peraturan Menteri
Kesehatan Republik Indonesia Nomor 32 tahun 2017. Dengan hasil tersebut kualitas air sumur atau tanah dangkal di sekitar Pit Antasena tergolong baik dan aman untuk digunakan sebagai air bersih. 
Tabel 1. Hasil Analisa Laboratorium Kualitas Air Sumur Penduduk Di Sekitar Void

\begin{tabular}{|c|c|c|c|c|c|c|}
\hline \multirow{2}{*}{ No } & \multirow{2}{*}{ TEST DESCRIPTION } & \multirow{2}{*}{\begin{tabular}{|c|}
$\begin{array}{c}\text { REGULATORY } \\
\text { UMMIT** }\end{array}$ \\
\end{tabular}} & \multirow{2}{*}{ UNIT } & \multirow{2}{*}{ METHOD } & \multicolumn{2}{|c|}{ SAMPUNG RESULT } \\
\hline & & & & & AT-1 & AT-2 \\
\hline & Physical Properties: & & & & & \\
\hline 1 & Odor & Tidak berbau & - & Organoleptic & Tidak Berbau & Tidak berbau \\
\hline 2 & Total Dissolved Solid, TDS* & 1500 & $\mathrm{mg} / \mathrm{L}$ & SNI 06-6989.27-2005 & 410 & 415 \\
\hline 3 & Turbidity* & 25 & NTU & 5.5-IK-GQA-027 & 0,8 & 0,6 \\
\hline 4 & Taste & Tidak berasa & - & Organoleptic & N/A & N/A \\
\hline 5 & Temperature* & Suhu udara \pm 3 & ${ }^{\circ} \mathrm{C}$ & 5.5-IK-GQA-003 & 28,5 & 28 \\
\hline \multirow[t]{2}{*}{6} & Color* & 50 & TCU & 5.4-IK-GQA-WQ-046 & $<1$ & $<1$ \\
\hline & Chemical Anorganic Properties: & & & & & \\
\hline 1 & Mercury, $\mathrm{Hg}^{*}$ & 0,001 & $\mathrm{mg} / \mathrm{L}$ & SNI 6989.78:2009 & $<0.00009$ & $<0.00009$ \\
\hline 2 & Arsenic, As & 0,05 & $\mathrm{mg} / \mathrm{L}$ & SNI 06-6989.54-2005 & $<0.01$ & $<0.01$ \\
\hline 3 & Iron, $\mathrm{Fe}^{*}$ & 1 & $\mathrm{mg} / \mathrm{L}$ & SNI 6989.4-2009 & 0,014 & 0,047 \\
\hline 4 & Fluoride, $\mathrm{F}^{*}$ & 1,5 & $\mathrm{mg} / \mathrm{L}$ & SNI 06-6989.29-2005 & $<0.024$ & 0,026 \\
\hline 5 & Cadmium, $\mathrm{Cd}^{*}$ & 0,005 & $\mathrm{mg} / \mathrm{L}$ & SNI 06-6989.38-2005 & $<0.00004$ & $<0.00004$ \\
\hline 6 & Hardness Total as $\mathrm{CaCO}_{3}{ }^{*}$ & 500 & $\mathrm{mg} / \mathrm{L}$ & SNI 06-6989.12-2004 & 142,8 & 140,4 \\
\hline 7 & Chloride, $\mathrm{Cl}^{* *}$ & 600 & $\mathrm{mg} / \mathrm{L}$ & SNI 6989.19:2009 & 25,5 & 25,2 \\
\hline 8 & Chromium hexavalent, $\mathrm{Cr}^{5+*}$ & 0,05 & $\mathrm{mg} / \mathrm{L}$ & SNI 6989.71:2009 & $<0.001$ & $<0.001$ \\
\hline 9 & Manganese, $\mathrm{Mn}^{*}$ & 0,5 & $\mathrm{mg} / \mathrm{L}$ & SNI 6989.5-2009 & 0,016 & 0,16 \\
\hline 10 & Nitrogen, Nitrate as $\mathrm{N}\left(\mathrm{NO}_{3}-\mathrm{N}\right)^{*}$ & 10 & $\mathrm{mg} / \mathrm{L}$ & 5.4-IK-GQA-WQ-043 & 1,5 & 1,5 \\
\hline 11 & Nitrogen, Nitrite as $\mathrm{N}\left(\mathrm{NO}_{2}-\mathrm{N}\right)^{*}$ & 1 & $\mathrm{mg} / \mathrm{L}$ & SNI 06-6989.9-2004 & 0,022 & 0,22 \\
\hline 12 & $\mathrm{pH}^{*}$ & $6.5-9.0$ & - & SNI 06-6989.11-2004 & 6,98 & 7,04 \\
\hline 13 & Selenium, Se & 0,01 & $\mathrm{mg} / \mathrm{L}$ & US EPA $7741 \mathrm{~A}$ & $<0.006$ & $<0.006$ \\
\hline 14 & Zinc, $Z n^{*}$ & 15 & $\mathrm{mg} / \mathrm{L}$ & SNI 6989.7.2009 & $<0.004$ & $<0.004$ \\
\hline 15 & Cyanide, $\mathrm{CN}^{*}$ & 0,1 & $\mathrm{mg} / \mathrm{L}$ & 5.4-IK-GQA-WQ-058 & $<0.02$ & $<0.02$ \\
\hline 16 & Sulphate, $\mathrm{SO}_{4}{ }^{2 * *}$ & 400 & $\mathrm{mg} / \mathrm{L}$ & SNI 6989.20:2009 & 5,7 & 5,75 \\
\hline \multirow[t]{2}{*}{17} & Lead, $\mathrm{Pb}^{*}$ & 0,05 & $\mathrm{mg} / \mathrm{L}$ & SNI 6989.46:2009 & $<0.0002$ & $<0.0002$ \\
\hline & Chemical Organic Properties: & & & & & \\
\hline 1 & Surfactants, MBAS* & 0,5 & $\mathrm{mg} / \mathrm{L}$ & SNI 06-6989.51-2005 & $<0.014$ & $<0.014$ \\
\hline \multirow[t]{2}{*}{2} & Total Organic Matter, $\mathrm{KMnO}_{4}{ }^{*}$ & 10 & $\mathrm{mg} / \mathrm{L}$ & SNI 06-6989.22-2004 & 4,3 & - \\
\hline & Biological Properties: & & & & & \\
\hline 1 & Total Coliform & 50 & $1 / 100$ & APHA 9221 ed 21 & 7 & 28 \\
\hline
\end{tabular}

-()$^{\circ}$ Accreditade by KAN

$\left.-l^{*+}\right)$ Clean Water Stand ard Quality Regulation, PerMenKes FI No. 32/2017

- The test results relate only to the items tested

- References sampling SNI 6989.58:2008

(Sumber: Hasil analisa laboratorium Global tahun 2017, Banjarmasin)

Dari sebagian warga yang membeli air untuk kebutuhan air minumnya, sebagian besar $(36,7 \%)$ mereka membeli air sejumlah kurang dari 100 liter per bulannya. Hanya sebagian kecil $(16,7 \%)$ saja warga yang membeli air di atas 100 liter perbulannya. Warga membeli air untuk air minum dengan menggunakan botol galon atau jerigen. 


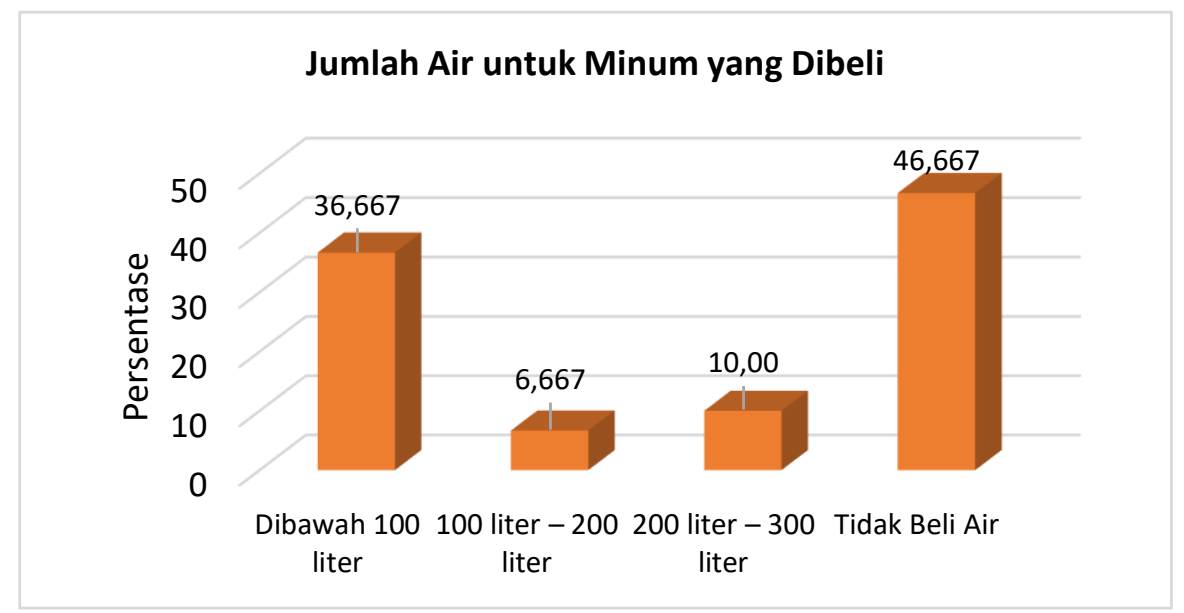

Gambar 8. Jumlah air untuk minum yang dibeli

Dari sebagian warga yang membeli air untuk kebutuhan air minumnya, sebagian besar $(36,7 \%)$ mereka membeli air sejumlah kurang dari 100 liter per bulannya. Hanya sebagian kecil $(16,7 \%)$ saja warga yang membeli air di atas 100 liter perbulannya. Warga membeli air untuk air minum dengan menggunakan botol galon atau jerigen.

Biaya yang dikeluarkan warga untuk membeli air untuk minum per bulan, sebagian besar (30\%) dibawah Rp. 50.000,-. Hanya sebagian kecil saja $(10 \%)$ warga yang mengeluarkan biaya di atas Rp. 200.000,- untuk pembelian air untuk minum per bulannya.

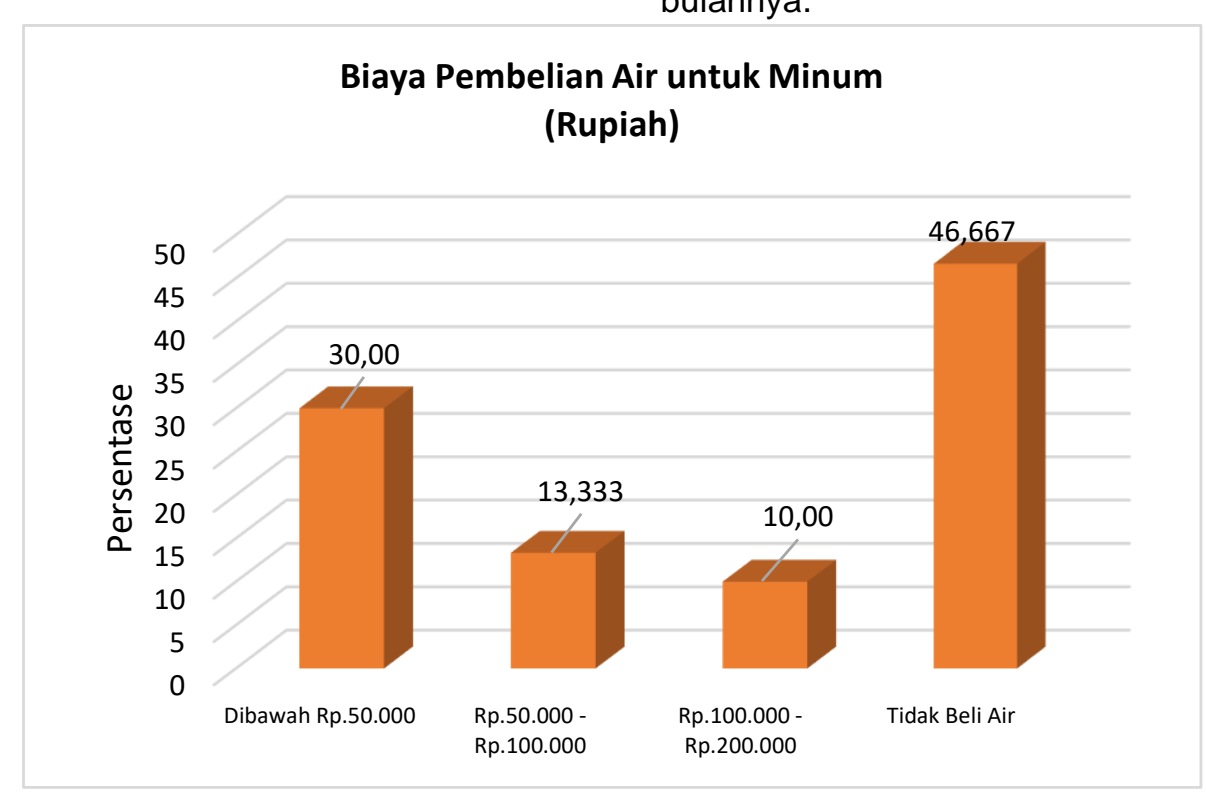

Gambar 9. Biaya pembelian air untuk minum 
Secara umum (76,7\%) warga menyatakan bahwa tidak ada pengaruh kesehatan dari adanya reservoir bekas tambang selama ini.
Penyakit yang dikeluhkan sebagian warga karena pengaruh reservoir bekas tambang yaitu diare, pusing dan influenza.

\section{Pengaruh adanya Void}

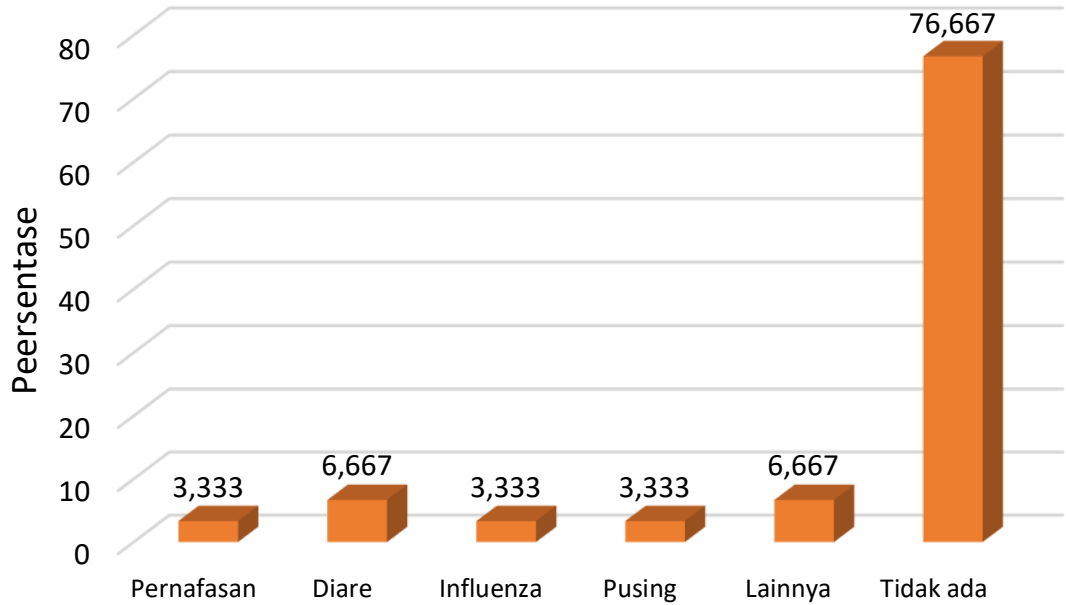

Gambar 10. Pengaruh adanya Void terhadap Warga

Sebagian besar (53,3\%) warga menyatakan bahwa tidak pernah ada penyakit yang meningkat di lingkungannya. Hanya sebagian kecil menyatakan terdapat beberapa

penyakit yang pernah meningkat di wilayah warga seperti malaria, diare, penyakit mata, cikunguya, batuk2 dan gatal2.

\section{Penyakit yang terjadi meningkat}

\section{di Lingkungan}

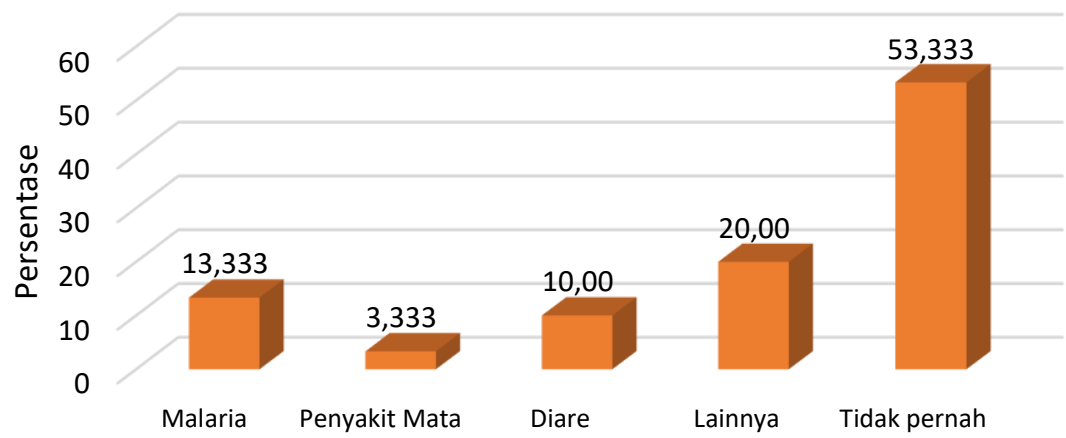

Gambar 11. Kasus Penyakit yang Meningkat 
Keberadaan reservoir bekas tambang batubara di PIT Antasena yang terbentuk tahun 2010 yang terletak di Desa Riam Adungan, sebagian besar $(86,7 \%)$ warga telah mengetahuinya. Hanya sebagian kecil saja warga tidak mengetahui keberadaan reservoir tersebut.

\section{Mengetahui Adanya Void}

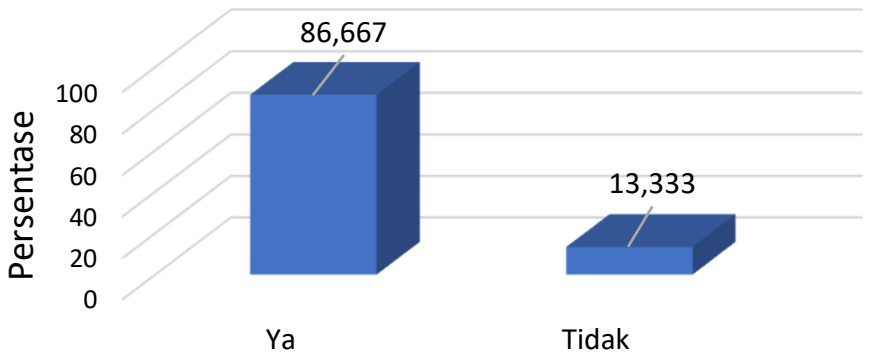

Gambar 12. Mengetahui Adanya Reservoir Bekas Tambang

Sebagian besar (50\%) warga menyatakan mengetahui keberadaan reservoir bekas tambang PIT Antasena tersebut karena pernah ke lokasi tersebut, selain itu mereka mengetahui dari sesama warga dan dari Kepala Desa. Bagi warga desa yang berada di Desa Salaman dan Riam Adungan lokasi reservoir tidaklah begitu jauh dapat ditempuh dengan berjalan kaki atau menggunakan motor.

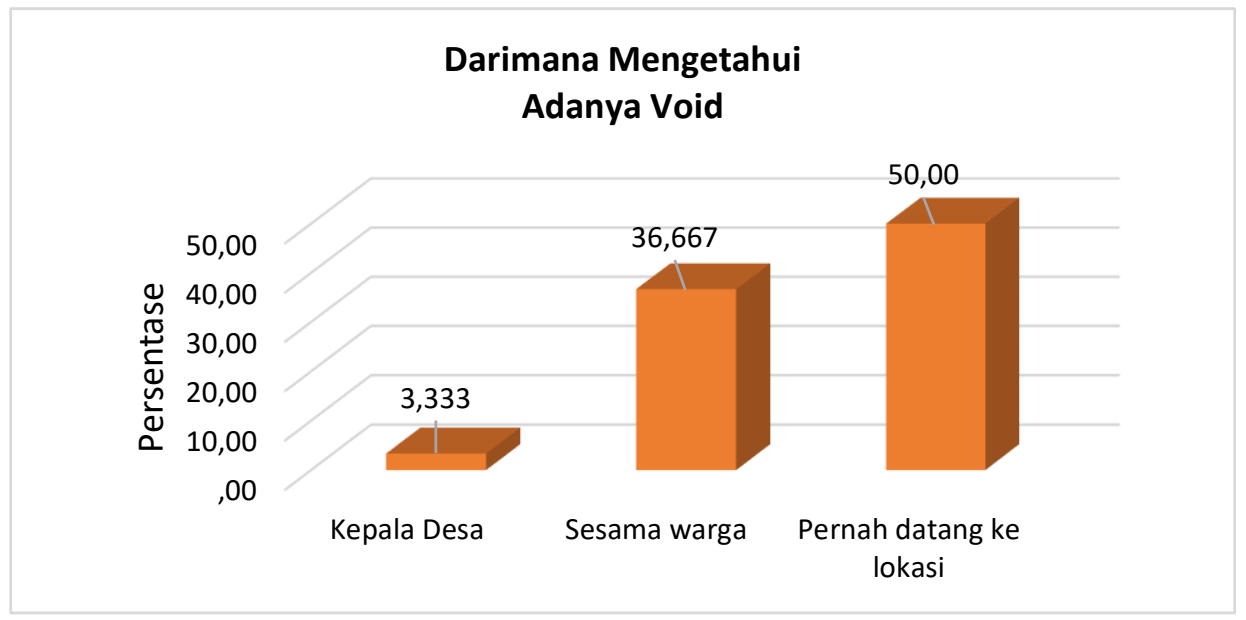

Gambar 13. Darimana Mengetahui Void

Rencana reservoir bekas tambang yang berada di dekat desa mereka akan digunakan sebagai sumber air bersih, semua warga menyatakan setuju (100\%) dengan rencana tersebut. Sehingga dengan adanya sumber air baku yang dapat diolah menjadi air bersih, akan dapat lebih bermanfaat dari segi kesehatan jika dibandingkan dengan mengkonsumsi air sungai. 


\section{Pendapat Tentang Void Akan Dijadikan Sumber Air Bersih}

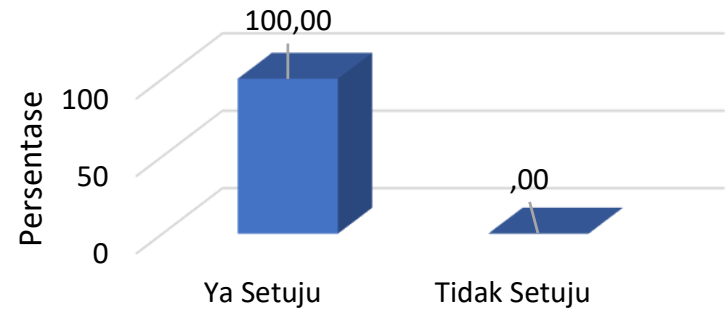

Gambar 14. Setujukah Reservoir Bekas Tambang Menjadi Sumber Air

Adanya reservoir bekas secara langsung terhadap warga di tambang selama ini sebagian besar sekitar reservoir tersebut $(86,7 \%)$ warga tidak ada pengaruh

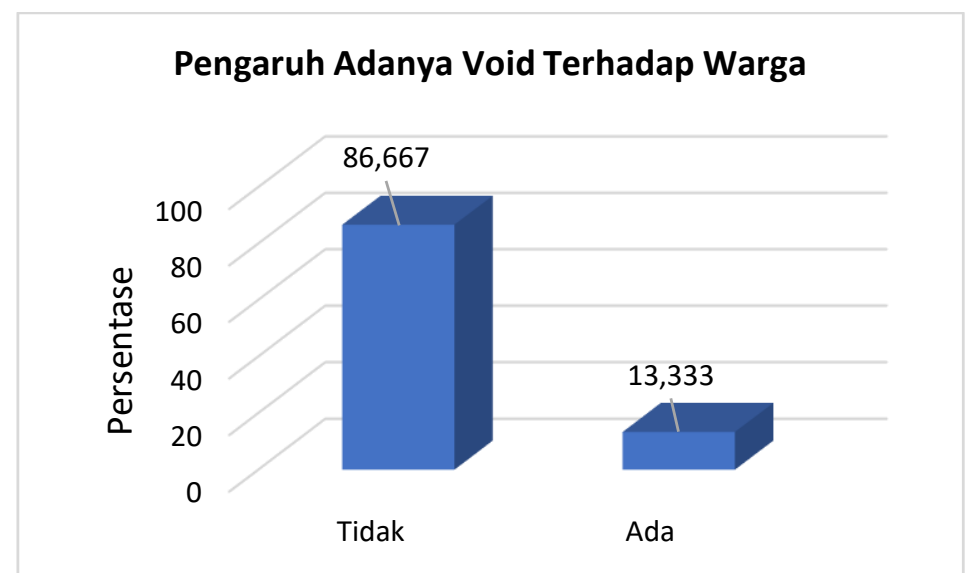

Gambar 15. Pengaruh Adanya Reservoir Bekas Tambang

Reservoir bekas tambang akan direncanakan sebagai sumber air, sebagian besar (50\%) warga menginginkan sumber air tersebut dapat digunakan sebagai air bersih dan juga sebagai air minum. 


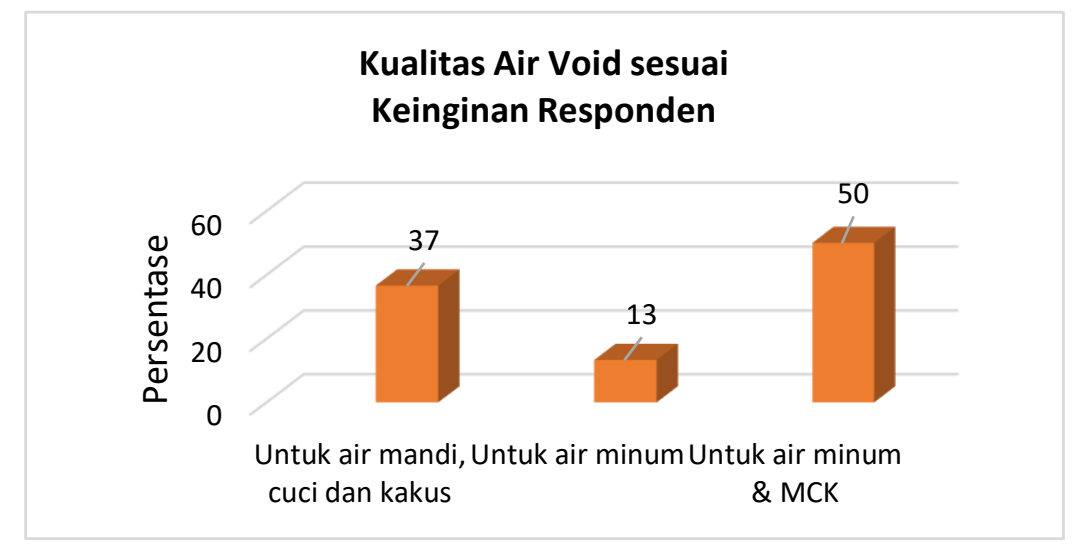

Gambar 16. Kualitas Air Yang Diinginkan Warga

Umumnya (60\%) warga tidak mempunyai pemikiran lain untuk pemanfaatan void selain sebagai sumber air. Sebagian warga mempunyai pemikiran lain selain sebagai sumber air yaitu sebagai obyek wisata, reservoir/tambak ikan nila, tempat pemancingan ikan atau untuk pengairan/irigasi sawah dan ladang.

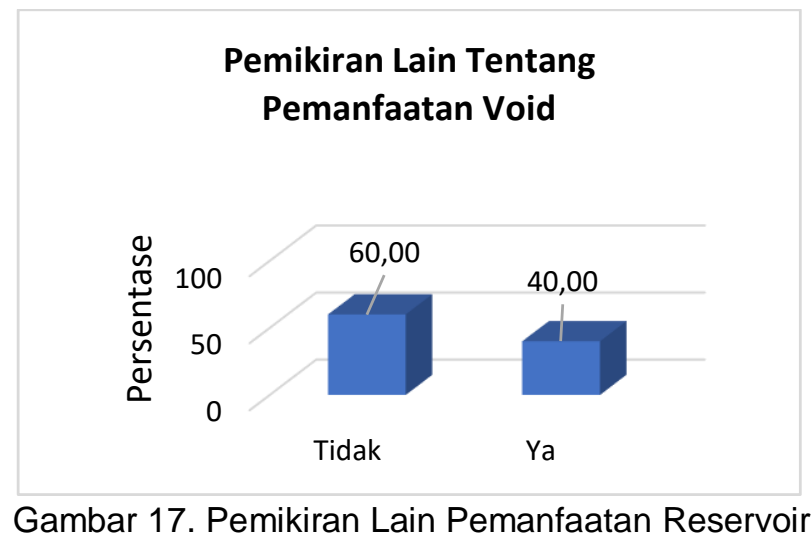

Umumnya warga (90\%) dan untuk tempat rekreasi. Hanya menyatakan perlu lahan bekas sebagian kecil saja warga tambang dimanfaatkan untuk menyatakan tidak perlu dimanfaatkan. perkebunan, tanaman buah, palawija 


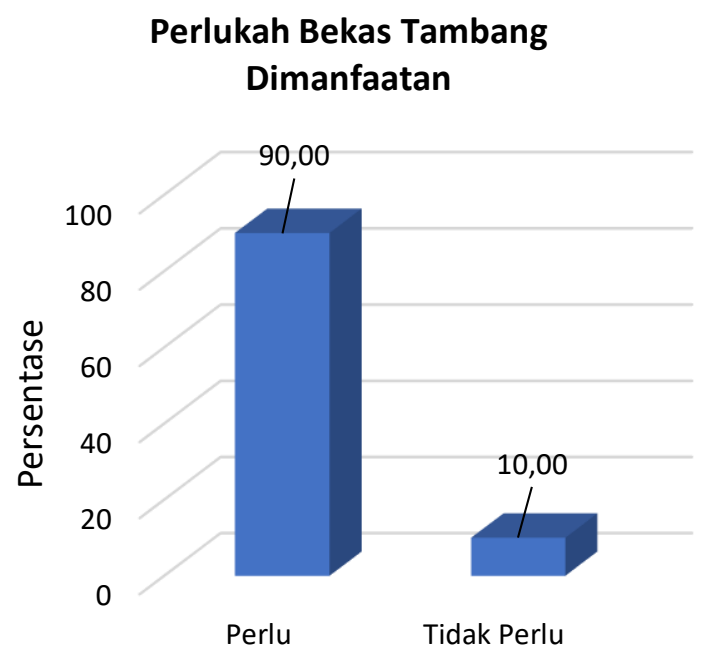

Gambar 18. Perlukah Pemanfaatan Lahan Bekas Tambang

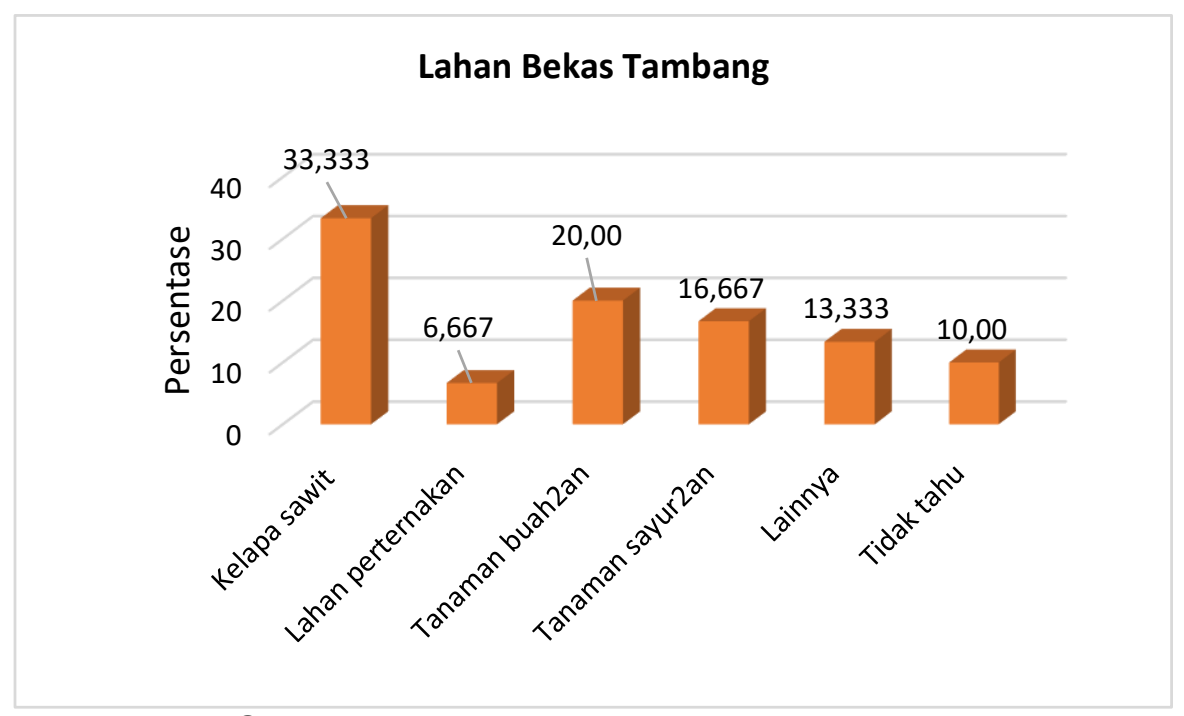

Gambar 19. Tanaman untuk Lahan Bekas Tambang 
Siapa pengelola reservoir tambang bekas tambang, menurut warga sebagian besar (26,7\%) menyatakan sebaiknya dikelola oleh perusahaan dan masyarakat, kemudian sebagian (23,3\%) lagi menyatakan sebaiknya dikelola oleh pemerintah daerah. Selain itu warga juga menyatakan bahwa reservoir bekas tambang sebaiknya dikelola pemerintah daerah bersama masyarakat.

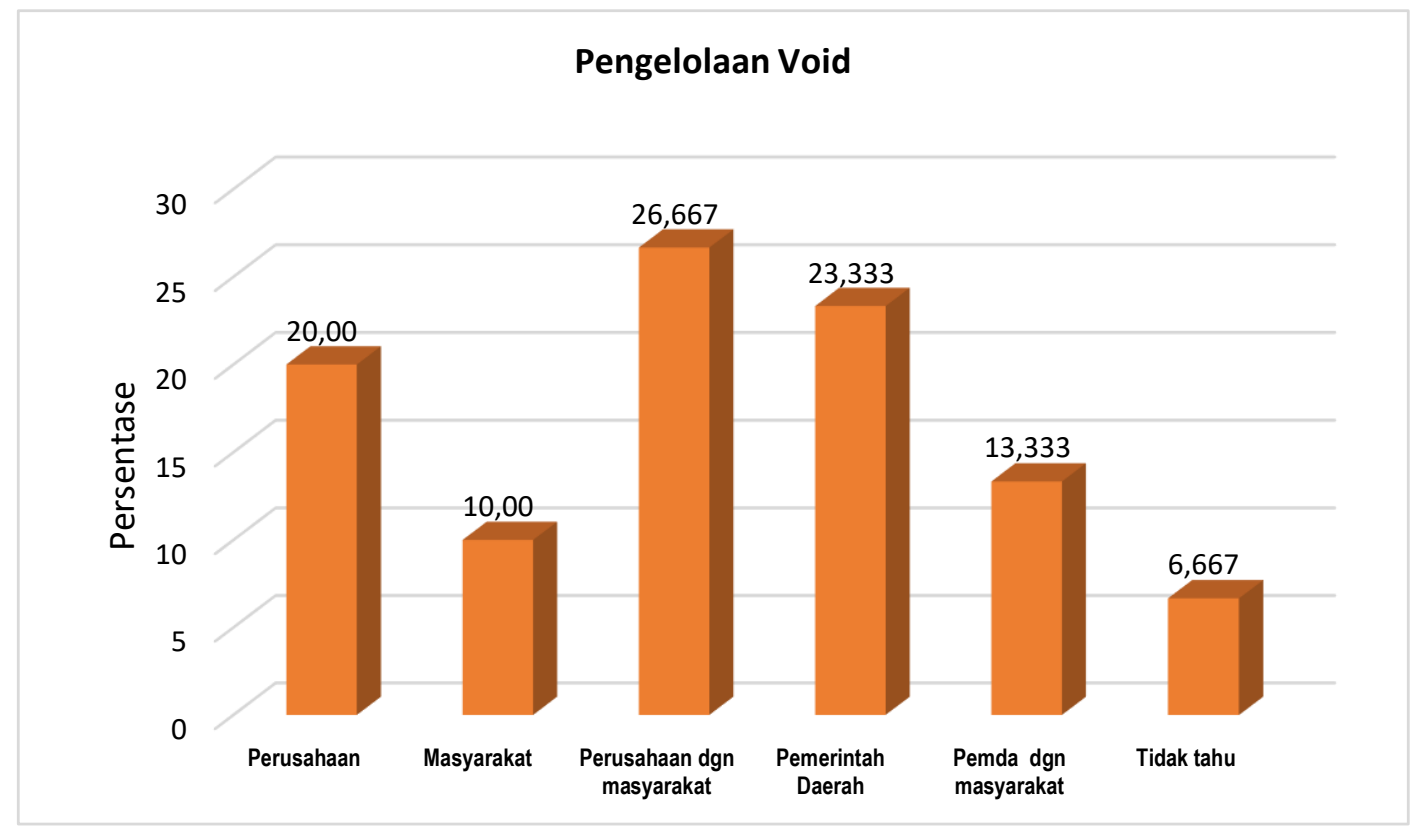

Gambar 20. Saran masyarakat untuk pengelolaan Void

\section{KESIMPULAN DAN SARAN}

\subsection{Kesimpulan}

Sebagian besar masyarakat mengatakan mereka sudah mengetahui keberadaan lubang bekas tambang di sekitar lokasi mereka. Umumnya mereka mengetahui keberadaan lubang bekas tambang karena pernah mengunjungi ke lokasi tersebut. Sebagian besar warga berpendapat bahwa tidak ada pengaruh secara langsung void terhadap warga di sekitarnya. Lubang bekas tambang telah lama terisi air dan direncanakan akan digunakan sebagai sumber air. Seluruh masyarakat mengatakan setuju dengan rencana tersebut yang akan digunakan sebagai sumber air. Sejak void bekas tambang ini terbentuk, sebagian besar masyarakat menyatakan tidak ada pengaruh secara langsung baik itu terhadap kesehatan maupun bagi kehidupan mereka.

Masyarakat sebagian besar menginginkan air void bekas tambang dapat dijadikan sebagai sumber air bersih sekaligus sebagai sumber air minum. Sebagian besar warga tidak mempunyai pemikiran lain untuk pemanfaatan bekas tambang selain sebagai sumber air. Tetapi sebagian kecil warga lainnya mempunyai pemikiran lain selain sebagai sumber air yaitu sebagai obyek wisata, reservoir/tambak ikan nila, tempat pemancingan ikan atau untuk pengairan/irigasi sawah dan ladang.Selain pemanfaatan lubang 
bekas tambang, terdapat sebagian besar warga menyatakan bahwa lahan bekas tambang perlu dimanfaatkan untuk perkebunan, tanaman buah, palawija dan untuk tempat rekreasi.Perkebunan yang cocok menurut warga adalah sawit, tanaman buah2an sayur2an dan tanaman akasia, padi serta jagung.

Siapa pengelola lubang tambang bekas tambang, menurut warga sebagian besar menyatakan sebaiknya dikelola oleh perusahaan dan masyarakat, Selain itu warga juga menyatakan bahwa lubang bekas tambang sebaiknya dikelola pemerintah daerah bersama masyarakat.

\subsection{Saran}

Karena tingkat pendidikan masyarakat cukup rendah perlu keterlibatan perusahaan dan pemerintah untuk meningkatkan pendidikan atau keterampilan masyarakat. Misalnya meningkatkan pemberian beasiswa pendidikan bagi siswa berprestasi, memberikan magang dan pelatihan serta tambahan ilmu pengetahuan lainnya.Masih rendahnya mata pencaharian sebagai petani, perlu ditingkatkan kondisi para petani. Misalnya meningkatkan pelaksanaan program-program yang mendukung kebutuhan pengembangan usaha pertanian.Kondisi jalan yang kurang baik khususnya ke lokasi reservoir tambang PIT Antasena merupakan hambatan masyarakat untuk akses ke lokasi reservoir bekas tambang apabila lokasi tersebut dijadikan lokasi obyek wisata atau lokasi pemancingan.

Masyarakat sekitar reservoir tambang sangat setuju dengan rencana reservoir sebagai sumber air khususnya untuk air bersih dan air minum, sehingga perlu dipersiapkan secara matang perencanaan reservoir sebagai sumber air baik kualitasnya maupun sistem pengolahannya. Perlu dipertimbangkan membangun unit pengolah air minum dengan sumber air dari reservoir untuk kebutuhan air minum pegawai PT. Arutmin. Hal ini untuk membuktikan bahwa sumber air dari reservoir aman untuk digunakan sebagai air minum. Alternatif lainnya selain pemanfaatan reservoir sebagai sumber air adalah menjadikan reservoir bekas tambang sebagai obyek wisata, tambak ikan nila dan tempat pemancingan ikan. Sehingga perlu dipersiapkan perencanaan dan pengelolaan obyek wisata seperti landscape, sarana, prasarana dan fasilitas wisatawan.Sebagian besar masyarakat menginginkan pengelolaan reservoir bekas tambang dilakukan oleh perusahaan bersama masyarakat. Hal yang perlu dilakukan bersama adalah melakukan beberapa uji coba kelayakan terhadap reservoir apabila akan digunakan sebagai air bersih atau sebagai tambak ikan, karena hal ini untuk mengetahui apakah air reservoir tersebut aman untuk dijadikan air bersih serta hasil produk ikan yang dihasilkan aman dikonsumsi oleh masyarakat.

\section{PERSANTUNAN}

Terimakasih kami sampaikan kepada pimpinan beserta manajemen PT. Arutmin Indonesia yang mempercayakan kepada BPPT untuk melakukan kajian ini serta kepada Direktur beserta para peneliti Pusat Teknologi Lingkungan-BPPT yang senantiasa mendukung kegiatan ini. 


\section{DAFTAR PUSTAKA}

Anonimous, 2016. Laporan Akhir Kajian Ketercapaian Target DMO Batubara Sebesar 60\% Produksi Nasional Pada Tahun 2019. Kementerian PPN/Bappenas.

Josua, M. 2012. Analisa Kelayakan Ekonomis Konversi Kapal Tanker 100000DWT Menjadi Kapal Bulk Carrier 106000DWT. Skripsi Fakultas Teknik Program Studi Teknik Perkapalan, Universitas Indonesia.

Sugiyono, 2013. Buku Metode Penelitian Kuantitatif dan R \& D. Penerbit Alfabeta, CV. Bandung.

Prijono Tjiptoherijanto, 2001. Proyeksi

Penduduk, Angkatan Kerja, Tenaga Kerja dan Peran Serikat Pekerja dan Peningkatan Kesejahteraan. Majalah Perencanaan Pembangunan Edisi 23 Th 2001.

Jati, Wasisto Raharjo, 2015. Bonus Demografi Sebagai Mesin Pertumbuhan Ekopnomi: Jendela Peluang atau Jendela Bencana di Indonesia. Jurnal Populasi Vol.23, No. 1, Hal. 1-19, 2015. Universitas Gadjah Mada.

AD Putri, D. Setiawina, 2013. Pengaruh Umur, Pendidikan, Pekerjaan Terhadap Pendapatan Rumah Tangga Miskin di Desa Bebandem. E-Jurnal Ekonomi Pembangunan, Universitas Udayana, Vol. 2, No. 4, April 2013 (hal.:173-180).

Kecamatan Kintap Dalam Angka 2017, Badan Pusat Statistik Kabupaten Tanah Laut.

Peraturan Menteri Kesehatan

Republik Indonesia Nomor 32 tahun 2017 